\title{
Urbanization and Major Ion Hydrogeochemistry of the Shallow Aquifer at the Effurun - Warri Metropolis, Nigeria
}

\author{
Irwin Anthony Akpoborie, Kizito Ejiro Aweto \& Oghenero Ohwoghere-Asuma \\ ${ }^{1}$ Department of Geology, Delta State University, Abraka, Nigeria \\ Correspondence: Irwin Anthony Akpoborie, Delta State University, Nigeria. E-mail: tony.akpoborie@gmail.com
}

Received: October 29, 2014 Accepted: November 10, 2014 Online Published: December 29, 2014

doi:10.5539/ep.v4n1p37 URL: http://dx.doi.org/10.5539/ep.v4n1p37

\begin{abstract}
Results from chemical analyses of forty dug well water samples in the Effurun-Warri metropolis show that mean $\mathrm{pH}$ is 7.1 and mean TDS is $193 \mathrm{mg} / \mathrm{l}$. Representative mean levels of cation occurrence include $\mathrm{Ca}, \mathrm{Mg}, \mathrm{Na}$ and $\mathrm{K}$ at $6.13 \mathrm{mg} / 1,4.09 \mathrm{mg} / \mathrm{l}, 4.89 \mathrm{mg} / \mathrm{l}$ and $3.37 \mathrm{mg} / 1$ respectively. Mean anion concentration for bicarbonate was $8.20 \mathrm{mg} / 1,1.27 \mathrm{mg} / 1$ for sulphate and $23.74 \mathrm{mg} / 1$ for chloride. Physical and chemical parameters are thus well below WHO and Standard Organization of Nigeria drinking-water quality standards. Piper diagram plots of the data indicate that ground water is predominantly $\mathrm{Ca}+\mathrm{Mg}+\mathrm{Na}$ Chloride facie and that mixing and ion exchange processes control the dominant cation in space and thus at each specific locality. Leachates from the many, widely distributed and unregulated landfills and dumpsites have been identified as possibly the principal sources of major ion loading to groundwater. The ubiquitous onsite sewage treatment soak away pits also contribute major ions to groundwater. These two sources are thus accountable for any observed local spikes in groundwater chloride content rather than sea water intrusion as had been previously suggested.
\end{abstract}

Keywords: urban water, leachates, major ions, dump sites, ion exchange, Niger Delta, Benin Formation

\section{Introduction}

The quality of ground water and surface water in the Effurun - Warri metropolis, the densely populated hub of the oil and gas industry in the western Niger Delta, Figure 1, Figure 2 has attracted considerable research interest because in the absence of reliable formal public water supply systems the majority of an estimated population of up to one million residents (Babatola \& Uriri, 2013), commerce and industry rely on self-supplies from dug wells and shallow boreholes. Thus, potential contamination of shallow groundwater with heavy metals from four primary sources have been suggested: oil and gas and related industry activities (Aremu, Olawuyi, Metshitsuka, Sridhar, \& Oluwande ,2002; Nduka \& Orisakwe, 2007, 2009; Emonyan, Akporhonor \& Akpoborie, 2008; Etchie, Etchie \& Adewuyi, 2011), leachates from unregulated garbage dumps (Akudo, Ozulu \& Osogbue , 2010), road wash and storm water runoff (Egboh, Nwajei \& Adaikpoh, 2000) and soils (Iwegbue, Nwajei, Ogala, \& Overah, 2010). In addition, Olobaniyi and Owoyemi (2004; 2007) have also suggested possible chloride enrichment of the underlying aquifer by recharge from the tidal Warri River and its tributary creeks and argue that heavy ground water abstractions in parts of the city are potentially inducing sea water intrusion from the Atlantic Ocean. The influences of all these factors on the major element geochemistry and the quality of groundwater are not well understood.

Furthermore, published research on the chemistry of water from the area has usually been devoid of geolocated data points and this has hitherto severely limited the identification and closer examination of any inherent spatial and possible temporal trends in the occurrence of chemical constituents in groundwater. Thus the objective of this paper is to provide a description of the major element geochemistry of groundwater using geo-referenced data and against which future evaluations and trends in this highly vulnerable and rapidly expanding urban environment may be compared. The results reported herein constitute part of a groundwater evaluation study, partial results from which have been reported by Akpoborie, Uriri and Efobo (2014).

\subsection{Study Area}

\subsubsection{Climate, Physiography and Drainage}

The Effurun-Warri metropolis lies roughly between latitude $5^{0} 30^{\prime} \mathrm{N}-5^{0} 45 \mathrm{~N}$ and longitude $5^{0} 15^{\prime} \mathrm{E}-5^{0} 50^{\prime} \mathrm{E}$, Figure 2 and enjoys a hot $\left(23^{\circ} \mathrm{C}-37^{\circ} \mathrm{C}\right)$ and humid (Relative Humidity, $50-70$ per cent) equatorial climate with 
a dry season that extends from about November to February, and a wet season that begins in March, peaks in July and October. 30-year mean annual rainfall is $3000 \mathrm{~mm}$ (Adejuwon, 2011).

The area rests mainly on the Sombreiro -Warri Deltaic Plain (SWP) one of the distinguishable physiographic landforms resulting from Recent and modern delta top deposition in the Niger Delta (Short \& Stauble, 1967; Allen,1965) the others being the Brackish Water and Mangrove Swamps (BMS) and the Fresh Water Swamps (FWS). The city is bound on its western edge by the BMS, swamp terrain that has so far limited city expansion in that direction.

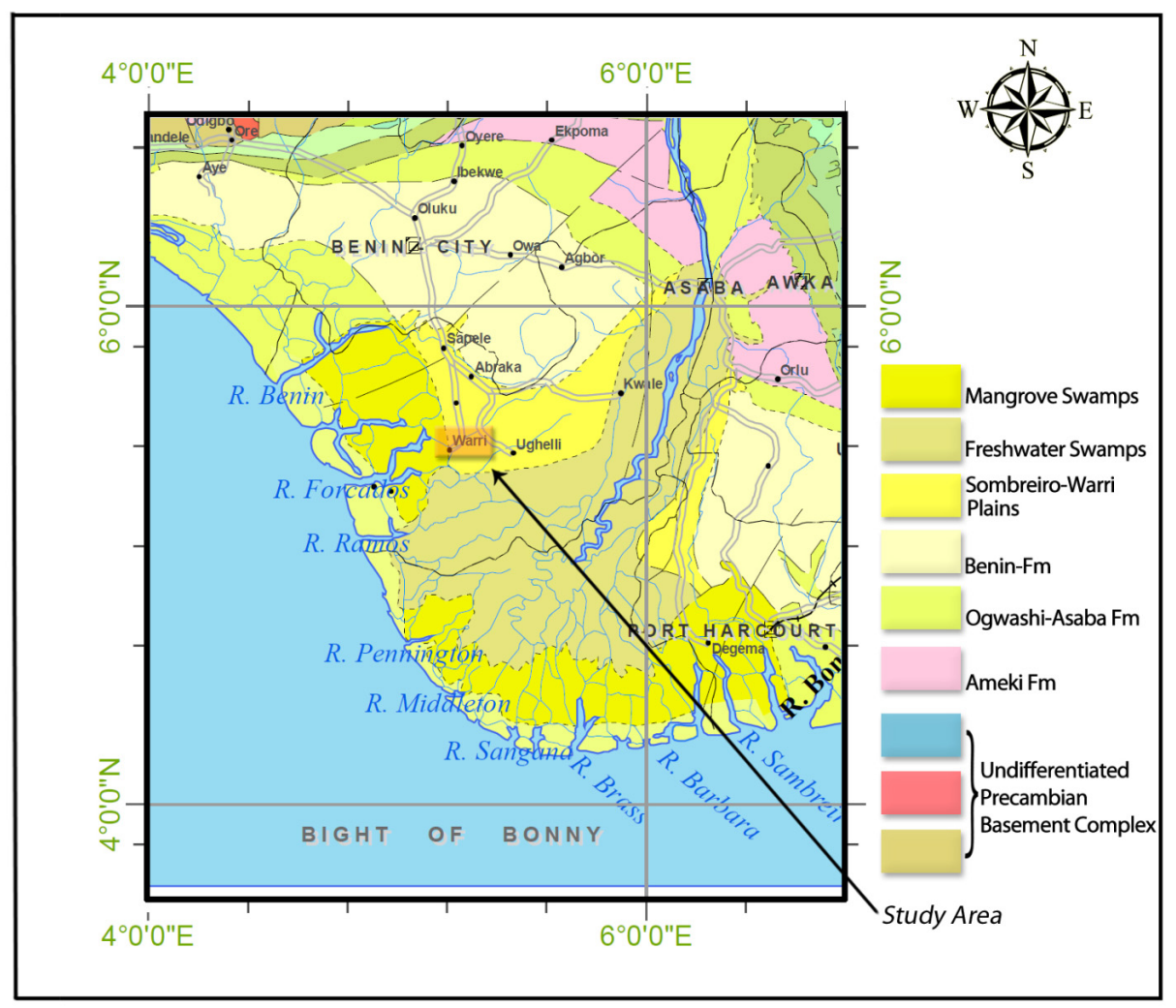

Figure1. Geological map of the western Niger Delta showing location of the Effurun-Warri Metropolis (Adapted from NGSA, 2004)

The Sombreiro -Warri Deltaic Plain is low lying, with an almost imperceptible seaward gradient and its lower parts merge with the water table and turn into swamps as evident in the Effurun-Warri metropolis. The area is circumscribed and drained by the tidal Warri River to the south and its tributary Ogunu/Edjeba Creek to the north, Figure 2. Mangroves line river banks especially in the western sector where they are sustained by weakly brackish water propagated landwards by a tidal regime.

\subsubsection{Geology and Groundwater Conditions}

The sedimentary fill of the late Quaternary delta top BMS and SWP physiographic terrains, Figure 1 has been described in the western Niger Delta by Akpoborie (2011) and in the eastern sector by Abam (2007) and Amajor (1991) and consists of an admixture of fine, to medium grained and coarse sands; silty clay and discontinuous thin clay layers. In the Effurun-Warri area, sandy layers are dominant up to $30 \mathrm{~m}$ below ground at Osubi and Ejeba neighborhoods (Olobaniyi \& Owoyemi, 2004), while further east Otobo, Aigbogun and Ifedili (2007) report the presence of up to $30 \mathrm{~m}$ thickness of clay in the shallow aquifer at Aladja. In the western river port part of the city that is located on the boundary zone between the SWP and the BMS, Akpoborie (1996) describes two $100 \mathrm{~m}$ deep boreholes that reveal a succession of black and gray colored silty clay and gravelly clay layers interbedded with coarse and medium grained sand beds. Because it has not been possible to distinguish between the younger Quaternary deposits and the Benin Formation proper in the subsurface, these delta top deposits are universally considered to be a continuation of the Benin Formation, Figure 1. 
These shallow deposits are exploited everywhere in the Niger Delta with dug wells and shallow boreholes for domestic water supplies. Specifically in the Effurun-Warri area where public water supplies are inadequate, homeowners rely on groundwater from shallow dug wells and relatively inexpensive boreholes that are predominantly less than $40 \mathrm{~m}$ deep. The dug wells and boreholes tap the medium to coarse - grained shallow aquifer sands. The permeability of the sands ranges from a reported $2.3 \times 10^{-5} \mathrm{~cm} / \mathrm{sec}$ to $3.8 \times 10^{-5} \mathrm{~cm} / \mathrm{sec}$ (Akpoborie, Ekakite \& Adaikpo, 2000; Olobaniyi \& Owoyemi, 2004; Niger Delta Development Commission, 2006). Deep regional groundwater flow in the Niger Delta region is reportedly in the west and south west direction (Ophori, 2007). In the Effurun -Warri area local flow in the shallow aquifer is controlled by a south westerly trending groundwater mound that extends from the Effurun GRA towards the neighborhood of Ekurede - Itsekiri and from which mound groundwater flows northwards, westwards, southwestwards and even eastwards (Akpoborie et al., 2014).

\section{Methodology}

Replicate water samples were collected from randomly located but evenly spread forty dug wells in the EffurunWarri metropolis during a sampling program that was undertaken in mid - October, 2011. New, one litre size polyethylene bottles were used for collection of water samples. Prior to collection, the bottles were each washed with clean water and cleaning reagents then thoroughly rinsed with distilled, deionised water. After the $\mathrm{pH}$, Total Dissolved Solids (TDS) and Electrical Conductivity (EC) were measured at point of collection, samples were sealed stored in ice chests and eventually transported to the laboratory within the hour of collection. The coordinates for selected sampling locations and associated codes are shown in Table 1 and Figure 2.

Electrical Conductivity and Total Dissolved Solids were measured in situ using the HACH Conductivity/TDS meters respectively. The $\mathrm{pH}$ was determined by means of a Schott Gerate model $\mathrm{pH}$ meter and the HACH Spectrophotometer was employed in determining the $\mathrm{NO}_{3}$ ion using the cadmium reduction method. $\mathrm{Na}$ and $\mathrm{K}$ ion concentrations were obtained with a Jenway Clinical flame photometer. Sulphate content was determined by turbidimetry and $\mathrm{Ca}, \mathrm{Mg}, \mathrm{HCO}_{3}$ and $\mathrm{Cl}$ with appropriate titrimetric methods as described by APHA (1992).

Table 1. Dug well water sampling locations at Effurun - Warri and sample codes used in the Piper and Stiff diagrams

\begin{tabular}{|c|c|c|}
\hline Coordinates & Street Address & Sample Code \\
\hline $\mathrm{N} 05^{0} 30.9 ; \mathrm{E}^{2} 05^{0} 49.13$ & Boro Street, Oruhuwhorun & Orw \\
\hline N05 $30.11 ; E 00549.16$ & Ero street, Oruhuwhorun & ORUWero \\
\hline $\mathrm{N} 05^{0} 29.0 ; \mathrm{E} 005^{0} 49.7$ & Apostolic Church, Aladja & Aladja \\
\hline $\mathrm{N} 05^{0} 29.5 ; \mathrm{E} 005^{0} 45.5$ & Umoji Compound, Aladja & AladjaUmoji \\
\hline $\mathrm{N} 05^{0} 34.4 ; \mathrm{E} 005^{0} 47.6$ & Arubayi Str Eff. GRA & Ef GRA \\
\hline $\mathrm{N} 05^{0} 31.14 ; \mathrm{E}^{2} 05^{0} 46.10$ & Inikoro Str Enerhen & enerhen \\
\hline $\mathrm{N} 05^{0} 31.8 ; \mathrm{E}_{00} 5^{0} 44.6$ & Ekpen Ajamimogha & Ajm \\
\hline $\mathrm{N} 05^{0} 34.8 ; \mathrm{E} 005^{0} 46.5$ & Army Barrack & ARM \\
\hline N05 $34.6 ; E 005^{0} 41.9$ & Tenumah Str, Ubeji & UBTem \\
\hline $\mathrm{N} 05^{0} 35.6 ; \mathrm{E}_{00} 5^{0} 33.9$ & Ubeji health Centre & UBH \\
\hline $\mathrm{N} 05^{0} 34.5 ; \mathrm{E}_{00} 5^{0} 41.13$ & Deeperlife Camp Rd & UBdpl \\
\hline $\mathrm{N} 05^{0} 34.6 ; \mathrm{E} 005^{0} 43.5$ & St Gregory Hospital, Ubeji & UBStG \\
\hline $\mathrm{N} 05^{0} 31.14 ; \mathrm{E}^{2} 05^{0} 43.12$ & Ekurede-Itsekiri & UB K-Itse \\
\hline $\mathrm{N} 05^{0} 30.8 ; \mathrm{E} 005^{0} 49.16$ & Abuja street, DSC Township & DSCAbj \\
\hline $\mathrm{N} 05^{0} 34.2 ; \mathrm{E}_{00} 5^{0} 44.11$ & Ekpan & Ekp \\
\hline N05 $32.6 ; E 005^{0} 45.14$ & Ugborikoko & Ogborik \\
\hline $\mathrm{N}^{0} 5^{0} 31.9 ; \mathrm{E} 005^{0} 44.12$ & Agbassa & Agbassa \\
\hline $\mathrm{N} 05^{0} 32.6 ; \mathrm{E}_{00} 5^{0} 45.14$ & Ugboroke close to dump site & Ugboroke \\
\hline $\mathrm{N} 05^{0} 34.8 ; \mathrm{E} 005^{0} 46.5$ & Mammy Market & MammyMkt \\
\hline $\mathrm{N} 05^{0} 30.8 ; \mathrm{E} 005^{0} 42.6$ & Ajamimogha & AJM2 \\
\hline
\end{tabular}


$\mathrm{N} 05^{0} 34.5 ; \mathrm{E} 005^{0} 43.5$

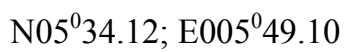

$\mathrm{N} 05^{0} 18.33$; $005^{0} 27.51$

$\mathrm{N} 05^{0} 34.6 ;{\mathrm{E} 005^{0} 47.8}^{\circ}$

$\mathrm{N} 05^{0} 31.9 ; \mathrm{E}_{00} 5^{0} 44.12$
Town Hall Ubeji

UBTH

70 Okuokoko

okuok

Iyara3

Dudu Crescent Eff. GRA

Okere
Iyara3

GRA

OK

\section{Results and Discussion}

\subsection{Water Chemistry}

\subsubsection{Physical and Chemical Characteristics}

Descriptive statistics of physical characteristics and major ion occurrence in ground water sampled at the different locations in the metropolis are shown in Table 2. Water ranges from mildly acidic, $\mathrm{pH} 5.2$ at Iyara to alkaline, $\mathrm{pH}, 8.9$ from a dug well near Ubeji Town Hall. Total Dissolved Solids (TDS) also varies widely from $545 \mathrm{mg} / \mathrm{l}$ at Ubeji to $19 \mathrm{mg} / \mathrm{l}$ at Abuja St., Steel Town, Aladja. Fifty seven per cent of all the samples showed a TDS of $200 \mathrm{mg} / \mathrm{l}$ or below while twenty five per cent have TDS of less than $100 \mathrm{mg} / \mathrm{l}$. The magnitude of range in spatial variation observed in all parameters suggests that mean values of parameters are of limited utility in describing shallow groundwater quality. However, on the basis of the data shown in Table 2, groundwater in the area is fresh and the major chemical constituents each occur at well below the limits specified in the WHO (2011) and SON (2007) drinking-water quality standards.

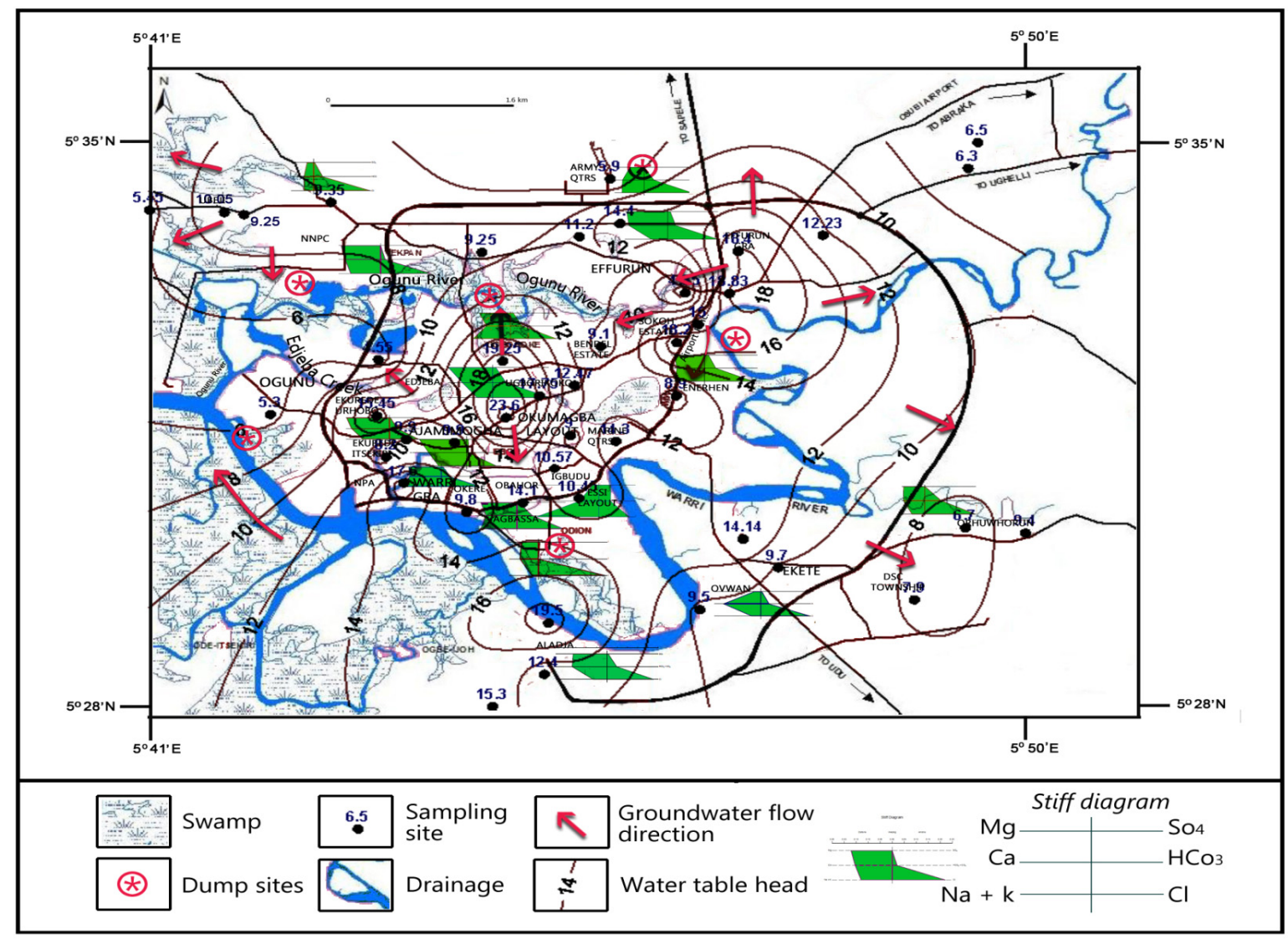

Figure 2. Map of Warri - Effurun area showing water table head distribution and Stiff pattern diagrams (Modified from Akpoborie, Uriri \& Efobo, 2014)

These results appear to be in general agreement with previous studies undertaken in the metropolis, a selection of which include those by Akudo et al. (2010), Olobaniyi and Efe (2007) and Olobaniyi and Owoyemi (2004; 2007). 
Table 2. Summary statistics of groundwater physical and chemical characteristics

\begin{tabular}{lllllll}
\hline $\mathbf{N}=\mathbf{4 0}$ & Min & Max & Range & Mean & Std. Deviation & SON (2007) \\
\hline $\mathrm{pH}$ & 5.2 & 8.9 & 3.7 & 7.1 & 1.04 & $6.5-9.2$ \\
$\mathrm{TDS}(m g / l)$ & 19 & 545 & 526 & 193.20 & 138.22 & 500 \\
$\mathrm{EC}$ & 22 & 1091 & 1069 & 381.14 & 272.50 & 500 \\
$\mathrm{Na}(m g / l)$ & 0.04 & 23.67 & 23.63 & 4.89 & 5.39 & 200 \\
$\mathrm{~K}(m g / l)$ & 0.05 & 16.43 & 16.38 & 3.37 & 3.91 & - \\
$\mathrm{Ca}(m g / l)$ & 0.25 & 29.03 & 28.78 & 6.13 & 5.97 & 75 \\
$\mathrm{Mg}(m g / l)$ & 0.07 & 18.70 & 18.63 & 4.09 & 4.21 & 50 \\
$\mathrm{HCO}(m g / l)$ & 0.43 & 24.71 & 24.28 & 8.20 & 6.50 & 500 \\
$\mathrm{SO}_{4}(m g / l)$ & 0.0 & 4.30 & 4.3 & 1.27 & 1.20 & 200 \\
$\mathrm{Cl}^{(m g / l)}$ & 1.59 & 104.21 & 102.62 & 23.74 & 22.0 & 200 \\
$\mathrm{NO}_{3}(m g / l)$ & 0.0 & 5.5 & 5.5 & 1.01 & 1.28 & 50 \\
\hline
\end{tabular}

\subsubsection{Major Ion Geochemistry}

The Piper (1944) diagram plot of analyses Figure 3 contains only selected samples because many samples plotted in the same position in both ternary diagrams and the central diamond. In order to reduce clutter many of such samples were removed from the diagram in order to reduce clutter. The ions plot linearly on the upper right quadrant of the Piper diamond reflecting variability and a well developed mixing trend that is also clearly reflected in the cation ternary plot. As a result of this, there appear to be no dominant cation and ground water is predominantly $\mathrm{Ca}+\mathrm{Mg}+\mathrm{Na}$ Chloride facie.

Data from Akudo et al. (2010) who suggested a relationship between dumpsite leachate chemistry and nearby borehole water quality have also been plotted in the Piper diagram, Figure 3. The leachate sample from this data, red circle plots in the lower quadrant of the diamond while borehole water (blue circle) is in near linear alignment with other dug well data. In the cation ternary diagram both borehole water and leachate plot together at the end point of a mixing line that is indicative and may be interpreted as a source of sodium enrichment (Smith \& Wahl, 2003). 

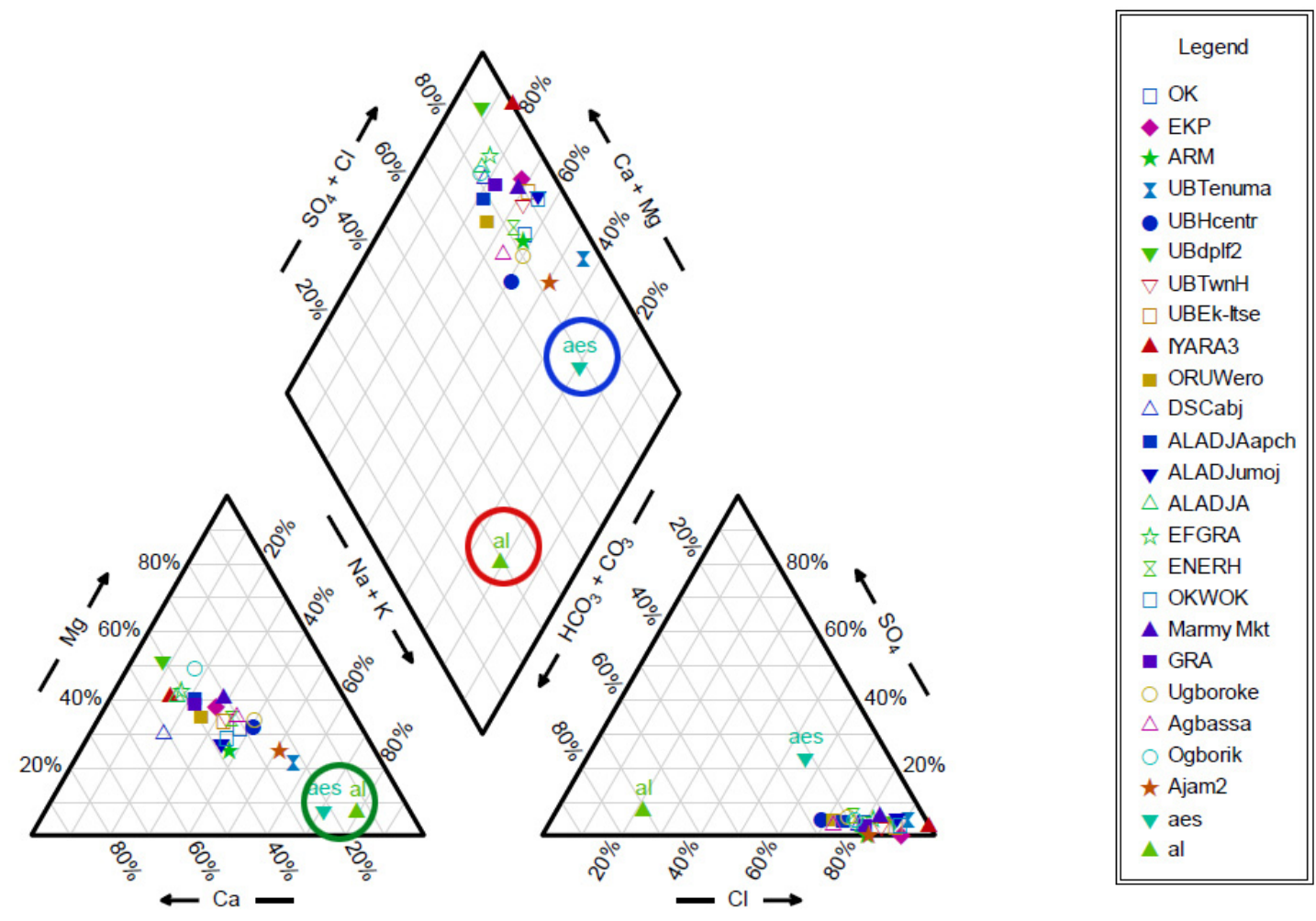

Figure 3. Piper diagram for dug well data and leachate data

Notes: al $=$ leachate from waste dump at Esisi area; aes = groundwater from domestic borehole near the waste dump; all other sample codes explained in Table 1. Data for the leachate and borehole water obtained from Akudo et al. (2010)

Dumpsite and landfill leachate and sewage are indeed known sources of chloride, bicarbonate, calcium and magnesium loading to native groundwater (Panno et al., 2006; Uma, 2004; Hanchar 1991; Bradley et al, 1987, Baedecker \& Back, 1979). Thus Akudo et al. (2010) report dumpsite leachate concentrations of up to $932 \mathrm{mg} / \mathrm{l}$, $2,208 \mathrm{mg} / 1,170 \mathrm{mg} / \mathrm{l}$ and $396 \mathrm{mg} / \mathrm{l}$ for $\mathrm{Na}, \mathrm{HCO}_{3}, \mathrm{SO}_{4}$ and $\mathrm{Cl}$ respectively from dumpsites in Warri, while Efe, Cheke and Ojoh (2013) show that up to twenty five huge and open garbage dumpsites and landfills are randomly located in the metropolis, Figure 2. This is in addition to the potentially tremendous amount of sewage generated by close to a million persons from numerous home and industrial onsite septic tank sewage treatment systems.

The shapes, and spatial distribution of Stiff (1951) diagrams derived from chemical analyses of water from selected locations, Table 3 and Figure 2, also suggest groundwater mixing and the resultant transitory nature of ground water chemistry within short distances in this urban setting. Ion exchange involving $\mathrm{Na}, \mathrm{Mg}$ and $\mathrm{Ca}$ is also suggested by the interchange in dominance of these ions in space as groundwater moves in the area. Mixing is enhanced by existing groundwater gradients that control complex and multiple directions of groundwater movement.

Thus while Aweto and Akpoborie (2011) identify the importance of water - rock interactions in determining the chemistry of shallow groundwater in the SWP deposits that occur in a more rural setting at Orerokpe, anthropogenic factors associated with urbanization in the Effurun-Warri area contribute significantly to ultimate groundwater chemistry. 
Table 3. Stiff Diagrams and cation sequences at selected locations at Effurun-Warri

\begin{tabular}{lll}
\hline Stiff Diagram & Sample location/ code & Cation sequence \\
\hline & Okere /ok & $\mathrm{Na}+\mathrm{k}>\mathrm{Ca}>\mathrm{Mg}$ \\
Ekurede Itsekiri / & $\mathrm{Mg}>\mathrm{Ca}>\mathrm{Na}+\mathrm{k}$ \\
Ubeji St Gregory's Hospital/ UbStG & $\mathrm{Mg}>\mathrm{Ca}>\mathrm{Na}+\mathrm{K}$ \\
& Iyara3 /Iyara3 & $\mathrm{Na}+\mathrm{k}>\mathrm{Ca}>\mathrm{Mg}$ \\
& Boro St, Oruworun/ Orw & $\mathrm{Ca}>\mathrm{Mg}>\mathrm{Na}+\mathrm{k}$ \\
& Ubeji health cmtr $/$ Ubhcentr & $\mathrm{Ca}>\mathrm{Mg}>\mathrm{Na}+\mathrm{k}$ \\
& Leachate ${ }^{* *}$ from Esisi dumpsite/al & $\mathrm{Na}+\mathrm{k}>\mathrm{Mg}>\mathrm{Ca}$ \\
& & $\mathrm{Na}+\mathrm{k}>\mathrm{Ca}>\mathrm{Mg}$ \\
& & $\mathrm{Na}+\mathrm{k}>\mathrm{Ca}>\mathrm{Mg}$
\end{tabular}

*Sample location code used in Table 1 and Piper Diagram, Figure 3

**Data obtained from Akudo et al. (2011)

However, potential direct recharge from an average annual $3000 \mathrm{~mm}$ rainfall is high as indicated by reported groundwater level fluctuation in the wet/dry seasons of up to $5 \mathrm{~m}$ (Akpoborie, Ekakite \& Adaikpoh, 2000) in the SWP. This would enhance dilution of contaminating leachate and sewage as it mixes with native groundwater moving through the shallow aquifer and also possibly explain the low occurrence of the nitrate ion in groundwater, Table 2 .

Therefore, evolution of groundwater chemistry in the shallow aquifer underlying the city appears to be driven by such factors as the infusion of dumpsite leachate that is an important source of bicarbonate, chloride and sodium ions into the system; direct recharge from mildly acidic and low pH rainwater (Efe, 2005, Olobaniyi \& Efe, 2007), flood water and storm water from drains and gutters (Gobo, Amangabara \& Agobie, 2014; Egboh, Nwajei, \& Adaikpoh, 2000), untreated sewage and finally, the complex ground water flow patterns (Akpoborie et al., 2014) that exist in the area. Omo-Irabor, Olobaniyi, Oduyemi and Akunna (2008) have also stressed the influence of anthropogenic factors in the determination of water chemistry in the Niger Delta region.

Sea water intrusion into the aquifer underlying Warri-Effurun has also been suggested as an important process in perceived elevated chloride levels in shallow groundwater by Olobaniyi and Owoyemi $(2004,2007)$ and Olobaniyi and Efe (2007) who argue that sea water intrusion results from excessive ground water abstraction and also from recharging water from the tide influenced Warri River. However, Warri River and tributary creeks are perennial gaining rivers (Akpoborie, et al., 2014)) and there is no evidence of heavy groundwater withdrawals in any part of the city that has caused a reversal of existing gradients. Indeed, the Warri River and its tributary creeks carry predominantly fresh water (Aghoghovwia, 2011; Ogbeibu, Chukwurah \& Oboh, 2011). Thus the presence of copious quantities of dump site-generated leachate and untreated sewage from ubiquitous septic tank 
soak- away pits in the metropolis suggests alternative and more credible sources of any and as has been shown, transitory chloride enrichment to shallow groundwater.

\section{Conclusion}

This study has shown that groundwater in the SWP deposits at the Effurun Warri metropolis has comparatively low mean TDS and major ions occur generally at levels that are well below SON and WHO drinking-water quality standards. However, because of rapid spatial and horizontal changes in major ion content, statistical mean values of major ion content should be used with caution.

Further, the evolution of groundwater chemistry in the shallow aquifer appears to be driven by urban induced factors that include infusion of dumpsite leachate that is an important source of bicarbonate, chloride and sodium ions into the system; direct recharge from acidic and low $\mathrm{pH}$ rainwater, flood water and storm water from drains and gutters, untreated sewage and finally, the complex ground water flow patterns that result from existing gradients and which enhance groundwater mixing.

\section{Acknowledgements}

Partial funding for this study was provided by the Center for Research in Water and Environment (CREWE), Abraka nd for which the authors are grateful.

\section{References}

Abam, T. K. S. (2007). N soil exploration and foundations in the Recent coastal areas of Nigeria. Bulletin of Engineering Geology and the Environment, 53, 13-9.

Adejuwon, O. A. (2012). Rainfall Seasonality in the Niger Delta Belt, Nigeria. Journal of Geography and Regional Planning, 5(2), 51-60. http://dx.doi.org/10.5897/JGRP11.096

Aghoghovwia, O. A. (2011). Physico-chemical characteristics of Warri River in the Niger Delta region of Nigeria. Journal of Environmental Issues and Agriculture in Developing Countries, 3(2), 40-46.

Akpoborie, I. A. (1996). Pollution from Oil in Delta State. In Environmental Issues in Delta State (pp. 49-59). Chevirol Resources Ltd., Ibadan.

Akpoborie, I. A. (2011). Aspects of the hydrology of the western Niger Delta wetlands: groundwater conditions in the Neogene (Recent) deposits of the Ndokwa area. Africa Geoscience Review, 18(3), 25-36.

Akpoborie, I. A., Ekakite, O. A., \& Adaikpoh, E. O. (2000) The Quality of Groundwater from Dug Wells in Parts of the Western Niger Delta. Knowledge Review, 2(5), $72-75$

Akpoborie, I. A., Uriri, A. E., \& Efobo, O. (2014). Ground Water Conditions and Spatial Distribution of Lead and Cadmium in the Shallow Aquifer at Effurun- Warri Metropolis, Nigeria. Environment and Pollution, 3(3), 27-37. http://dx.doi.org/10.5539/ep.v3n3p27

Akudo, E. O., Ozulu, G. U., \& Osogbue, L. C. (2010). Quality Assessment of groundwater in selected waste dump site areas in Warri. Environmental Research Journal, 4(4), 281-285. http://dx.doi.org/10.3923/erj.2010.281.285

Allen, J. R. L. (1965). Late Quaternary Niger Delta and Adjacent Areas: Sedimentary Environments and Lithofacies. Bulletin American Association of Petroleum Geologists, 49(5), 547-600.

Amajor, L. C. (1991). Aquifers in the Benin Formation (Miocene Recent), Eastern Niger Delta, Nigeria: Lithostratigraphy, Hydraulics, and Water Quality. Environ Geol Water Sci., 17(2), 85-101. http://dx.doi.org/10.1007/BF01701565

APHA. (1992). Standard methods for the examination of water and waste water (18th ed.). American Public Health Association, Washington, D.C.

Aremu, D. A., Olawuyi, J. F., Metshitsuka, S., Sridhar, M. K., \& Oluwande, P. A. (2002). Heavy metal analysis of groundwater from Warri, Nigeria. International Journal of Environmental Health Research, 12(3), 261-267 http://dx.doi.org/10.1080/0960312021000001014

Aweto, K., \& Akpoborie, I. A. (2011). Geo-Electric and Hydrogeochemical Mapping of Quaternary Deposits at Orerokpe in the Western Niger Delta. J. Appl. Sci. Environ. Manage., 15(2), 351-359.

Babatola, O., \& Uriri, A. (2013). Assessment of Maternal Health Intervention Programme of Delta State, Nigeria:Application of the U.N Process Indicators. Journal of Public Policy and Administration Research, $3(9), 62-71$. 
Baedecker, M., \& Back, W. (1979). Hydrogeological Processes and Chemical reactions at a landfill. Groundwater, 17(5), 429-437. http://dx.doi.org/10.1111/j.1745-6584.1979.tb03338.x

Efe, S. I. (2005). Urban effects on precipitation amount and rainwater quality in Warri metropolis, (Unpublished Ph.D. Thesis) Delta State University, Abraka, Nigeria.

Efe, S. I., Cheke, L. A., \& Ojoh, C. O. (2013). Effects of Solid Waste on Urban Warming in Warri Metropolis, Nigeria. Atmospheric and Climate Sciences, 3, 6-12. http://dx.doi.org/10.4236/acs.2013.34A002

Egboh, S. H. O., Nwajei, G. E., \& Adaikpoh, E. O. (2000). Selected Heavy metals concentration in sediments from major roads and gutters in Warri, Delta State, Nigeria. Nig. J. Sc. Env., 2, 105-111.

Emoyan, O. O., Akporhonor, E. E., \& Akpoborie, I. A. (2008). Environmental Risk Assessment of River Ijana, Ekpan, Delta State. Chem. Spec. and Bioavailability, 20(1), 23-32. http://dx.doi.org/10.3184/095422908X295825

Etchie, T. O., Etchie, A. T., \& Adewuyi, G. O. (2011). Source Identification of Chemical Contaminants in Environmental Media of a Rural Settlement. Research Journal of Environmental Sciences, 5, 730-740, http://dx.doi.org/10.3923/rjes.2011.730.740

Gobo, A. E., Amangabara, G. T., \& Agobie, O. (2014). Impacts of Urban Land use changes on flood events in Warri, Delta State Nigeria. Int. Journal of Engineering Research and Applications, 4(9), 48-60.

Hanchar, D. W. (1991). Effects of septic-tank effluent on ground-water quality in northern Williamson County and southern Davidson County, Tennessee U. S. Geological Survey Water-Resources Investigations Report 91-4011.

Iwegbue, C. M., Nwajei, G. E., Ogala, J. E., \& Overah, C. L. (2010). Determination of trace metal concentrations in soil profiles of municipal waste dumps in Nigeria. Environ Geochem Health, 32, 415-430 http://dx.doi.org/10.1007/s10653-010-9285-y

Nduka, J. K., \& Orisakwe, O. E. (2007). Heavy Metal Levels and Physico - Chemical Quality of Potable Water Supply in Warri, Nigeria. Annali di Chimica, 97, 867-874. http://dx.doi.org/10.1002/adic.200790071

Nduka, J. K., \& Orisakwe, O. E. (2009). Effect of Effluents from Warri Refinery Petrochemical Company WRPC on Water and Soil Qualities of "Contiguous Host" and "Impacted on Communities" of Delta State, Nigeria. The Open Environmental Pollution \& Toxicology Journal, 1, 11-17. http://dx.doi.org/10.2174/1876397900901010011

Niger Delta Development Commission. (2006). Environmental Impact Assessment of the proposed Iyara Sand Fill Project, Document NDDC-005, NDDC Port Harcourt, Nigeria.

Nigeria Geological Survey Agency. (2004). Geological Map of Nigeria, NGSA, Abuja, Nigeria.

Ogbeibu, A. E., Chukwurah, A. E., \& Oboh, I. P. (2013). Effects of Open Waste Dump-site on its Surrounding Surface Water Quality in Ekurede-Urhobo, Warri, Delta State, Nigeria. Natural Environment, 1(1), 1-16. http://dx.doi.org/ 10.12966/ne.06.01.2013

Olobaniyi, S. B., \& Efe, S. I. (2007). Comparative assessment of rainwater and groundwater quality in an oil producing area of Nigeria: environmental and health implications. Jnl Env Health Res, 6(2), 111-117.

Olobaniyi, S. B., \& Owoyemi, F. B. (2004). Quality of Groundwater in Deltaic Plain Sands Aquifer of Warri and Environs, Delta State, Nigeria. Water Resources, 15, 38-45.

Olobaniyi, S. B., \& Owoyemi, F. B. (2007). Characterization by factor analysis of the chemical facies of groundwater in the Deltaic Plain Sands Aquifer of Warri, western Niger Delta, Nigeria. African Journal of Science and Technology (AJST) Science and Engineering Series, 7(1), 73-81.

Omo-Irabor, O. O., Olobaniyi, S, B., Oduyemi, K., \& Akunna, J. (2008). Surface and groundwater water quality assessment using multivariate analytical methods: A case study of the Western Niger Delta, Nigeria. Physics and Chemistry of the Earth, 33, 666-673. http://dx.doi.org/10.1016/j.pce.2008.06.019

Ophori, D. U. (2007). A simulation of large scale groundwater flow in the Niger Delta, Nigeria. Env. Geosciences, 14(4), 181-195. http://dx.doi.org/10.1306/eg.05240707001

Otobo, E., Aigbogun, C. O., \& Ifedili, S. O. (2007). Geoelectrical Evaluation of Waste Dump Sites at Warri and its Environ, Delta State, Nigeria. J. Appl. Sci. Environ. Manage., 11(2), 61-64.

Panno, S. V., Hackley, K. C., Hwang, H. H., Greenberg, S., Krapac, I. G., Landsberger, S., \& O’Kelly, D. J. (2006). Characterization and identification of the sources of $\mathrm{Na}-\mathrm{Cl}$ in ground water. Ground Water, 44(2), 
176-187. http://dx.doi.org/10.1111/j.1745-6584.2005.00127.x

Piper, A. M. (1944). A graphic procedure in geochemical interpretation of water analyses. Trans. Am. Geophys. Union, 25, 914-923. http://dx.doi.org/10.1029/TR025i006p00914

Short, K. C., \& Stauble, A. J. (1967). Outline of geology of Niger delta. Bull. Amer. Assoc. Petr. Geol., 54(5), 761-779.

Smith, S. J., \& Wahl, K. L. (2003). Changes in streamflow and summary of major-ion chemistry and loads in the North Fork Red River Basin upstream from Lake Altu, northwestern Texas and western Oklahoma, 1945-1999, USGS Water Resources Investigation Report 03-1999.

Standards Organization of Nigeria. (2007). Nigerian Standard for Drinking Water Quality NIS 554:2007. Abuja, Nigeria.

Stiff, H. A. Jr. (1951). The interpretation of chemical water analysis by means of patterns. Journal of Petroleum Technology, 3(10), 15-17. http://dx.doi.org/10.2118/951376-G

Uma, K. O. (2004). Hydrogeology of the perched aquifer systems in the hilly terrains of Nsukka Town, Enugu State, S.E.Nigeria, Water Resources, 14, 85-92.

WHO. (2011). Guidelines for drinking-water quality (4th ed.). Retrieved from http://www.who.int

\section{Copyrights}

Copyright for this article is retained by the author(s), with first publication rights granted to the journal.

This is an open-access article distributed under the terms and conditions of the Creative Commons Attribution license (http://creativecommons.org/licenses/by/3.0/). 